\title{
Real Time in vivo Imaging of Tissue Factor-Induced Thrombus Formation
}

\author{
Bruce Furie Barbara C. Furie \\ Harvard Medical School, Beth Israel Deaconess Medical Center, Boston, Mass., USA
}

Using a laser-induced endothelial injury model, we examined thrombus formation in the microcirculation of wild type and genetically altered mice by real time in vivo confocal and widefield microscopy to analyze this complex physiologic process in a native system. Following endothelial injury, platelet adhesion leads rapidly to thrombus formation. We analyzed the kinetics of platelet P-selectin expression and leukocyte rolling during this process. P-selectin and CD41 expression were visualized by confocal microscopy in optical slices of a developing arterial thrombus. Immediately after injury, P-selectin was visible at the vascular wall-thrombus interface, and a wave front of P-selectin migrated from the vessel wall to the luminal edge of the thrombus over time. To assess whether $\mathrm{P}$-selectin in arterial thrombi is functional, we examined thrombi for interaction with leukocytes. In wild type mice, we observed leukocyte rolling on arterial thrombi about 4 min after injury but no rolling earlier. Maximal leukocyte rolling on thrombi was observed after 8 min. Leukocyte rolling was minimal in P-selectin- and PSGL-1 deficient mice. Transfusion of platelets from wild type mice into P-selectin deficient mice restored leukocyte rolling on thrombi.

We observed P-selectin expression, tissue factor accumulation and fibrin generation following platelet localization in the developing thrombus in arterioles of wild type mice. However, mice lacking PSGL-1 or P-selectin, or wild type mice infused with blocking P-selectin antibodies, developed platelet thrombi containing minimal tissue factor and fibrin. To explore the delivery of tissue factor into a developing thrombus, we identified microparticles in platelet-poor plasma that express tissue factor and PSGL-1. Fluorescently labeled mouse microparticles infused into a recipient mouse localized within the developing thrombus in wild type mice but not P-selectin null mice, indicating that one pathway for the initiation of blood coagulation in vivo involves the accumulation of tissue factor- and PSGL-1-containing microparticles in the platelet thrombus expressing P-selectin. These microparticles bind to activated platelets in an interaction mediated by platelet P-selectin and microparticle PSGL-1.

Low tissue factor mice, provided by Dr. Nigel Mackman (Scripps Research Institute), were used to determine the source of tissue factor that accumulates in the thrombus in vivo. These mice generate platelet thrombi following endothelial injury but show minimal tissue factor or fibrin in the growing thrombus. Bone marrow transplantation from wild type mice into low tissue factor mice rescued the ability of these chimeras to generate platelet thrombi containing tissue factor and fibrin. Bone marrow transplantation from low tissue factor mice into wild type mice generated mice that initially formed thrombi containing tissue factor and fibrin, albeit in reduced quantity. As the platelet thrombus grows, it fails to recruit increased tissue factor and fibrin. These results indicate that tissue factor in thrombi generated in this thrombosis model is primarily derived from hematopoietic cells. However, some nonhematopoietically-derived tissue factor, presumably associated with the vessel wall, generates small but critical amounts of tissue factor following initial injury leading to fibrin formation. Tissue factor is not required for generation of the platelet thrombus.

\begin{tabular}{ll}
\hline KARGER & (c) 2003 S. Karger AG, Basel \\
1424-8832/03/0337-0026\$19.50/0 \\
$\begin{array}{l}\text { Eax +4161306 1234 } \\
\text { www.karger.com }\end{array}$ & $\begin{array}{l}\text { Accessible online at: } \\
\text { www.karger.com/journals/pht }\end{array}$
\end{tabular}

Bruce Furie

Harvard Medical School, Beth Israel Deaconess Medical Center

330 Brookline Avenue, Boston, MA 02215 (USA)

Tel. + 1617 6670620, Fax + 16179755505

E-Mail bfurie@caregroup.harvard.edu 
In summary, analysis of thrombus formation in vivo via confocal and widefield imaging of the microcirculation of a living mouse permits study of this complex physiologic process in a system that includes the vessel wall, the presence of flowing blood and the absence of anticoagulants. Following up on our original observation in 1992 that blockade of P-selectin function inhibits fibrin formation, we have now established a P-selectin/PSGL-1 dependent pathway of blood coagulation involving tissue factor derived from hematopoietic cells.

\section{Acknowledgments}

We are grateful to our laboratory colleagues for their contributions to the experiments described.
References Furie B: Real time in vivo imaging of platelets, tissue factor and fibrin during arterial thrombus formation in the mouse. Nature Medicine 2002;8:1175-1181.

Falati S, Liu Q, Gross P, Merrill-Skoloff G, Chou J, Vandendries E, Celi A, Croce K, Furie BC, Furie B: Accumulation of tissue factor into developing thrombi in vivo requires microparticle PSGL-1- and platelet P-selectin. J Exp Med 2003;197(11):1585-1598.

Palabrica T, Lobb R, Furie BC, Aronowitz M, Benjamin C, Hsu Y-M, Sajer SA, Furie B: Leukocyte accumulation which promotes fibrin deposition is mediated in vivo by P-selectin (CD62) on adherent platelets. Nature 1992;359: 848-851. 